\title{
Evaluation of Antimicrobial Activity in Ethanolic Extract of Caralluma indica
}

\author{
G. Gnanashree ${ }^{1 *}$, P. Mohamed Sirajudeen ${ }^{2}$ \\ ${ }^{1}$ Dept. of Chemistry, Khadir Mohideen College, Adirampattinam-614 701, Tamil Nadu, India \\ ${ }^{2}$ Dept. of Chemistry, Khadir Mohideen College, (Autonomous), Adirampattinam-614 701, Tamil Nadu, India \\ *Corresponding author: drpmsiraij@yahoo.in
}

Available online at: www.isroset.org

Received: 23/Nov/2018, Accepted: 11/Dec/2018, Online: 31/Dec/2018

\begin{abstract}
In the present study to investigate the antimicrobial activity in Caralluma indica. Antibacterial activity showed about $3.92 \mathrm{~mm}(50 \mu \mathrm{l}), 6.11 \mathrm{~mm}(100 \mu \mathrm{l}), 8.25 \mathrm{~mm}(150 \mu \mathrm{l})$ and $10.98 \mathrm{~mm}$ (Std.) zone against the test organisms of Escherichia coli. $4.08 \mathrm{~mm}(50 \mu \mathrm{l}), 6.23 \mathrm{~mm}(100 \mu \mathrm{l}), 8.47 \mathrm{~mm}(150 \mu \mathrm{l})$ and $11.65 \mathrm{~mm}$ (Std.) zone against the test organisms of Staphylococcus aureus. $2.17 \mathrm{~mm}(50 \mu \mathrm{l}), 4.86 \mathrm{~mm}(100 \mu \mathrm{l}), 6.13 \mathrm{~mm}(150 \mu \mathrm{l})$ and $9.46 \mathrm{~mm}$ (Std.) zone against the test organisms of Bacillus subtilis. $4.85 \mathrm{~mm}(50 \mu \mathrm{l}), 7.32 \mathrm{~mm}(100 \mu \mathrm{l}), 9.69 \mathrm{~mm}(150 \mu \mathrm{l})$ and $12.13 \mathrm{~mm}$ (Std.) zone against the test organisms of Pseudomonas aeruginos. Antifungal activity showed about $1.95 \mathrm{~mm}(50 \mu \mathrm{l}), 4.20 \mathrm{~mm}(100 \mu \mathrm{l}), 6.10 \mathrm{~mm}(150 \mu \mathrm{l})$ and $10.42 \mathrm{~mm}$ (Std.) zone against the test organisms of Candida albicans. $0.90 \mathrm{~mm}(50 \mu \mathrm{l}), 2.81 \mathrm{~mm}(100 \mu \mathrm{l}), 5.72 \mathrm{~mm}(150 \mu \mathrm{l})$ and $8.10 \mathrm{~mm}$ (Std.) zone against the test organisms of Aspergillus flavus. $0.35 \mathrm{~mm}(50 \mu \mathrm{l}), 1.10 \mathrm{~mm}(100 \mu \mathrm{l}), 3.66 \mathrm{~mm}(150 \mu \mathrm{l}) \mathrm{and} 7.90 \mathrm{~mm}$ (Std.) zone against the test organisms of Aspergillus niger.
\end{abstract}

Keyword: Caralluma indica, Escherichia coli, Staphylococcus aureus, Bacillus subtilis, Pseudomonas aeruginosa, Candida albicans, Aspergillus flavus, Aspergillus niger.

\section{INTRODUCTION}

In the modern world multiple drug resistance has developed against many microbial infections due to the indiscriminate use of commercial antimicrobial drugs commonly used in the treatment of infectious disease. In addition to this problem, antibiotics are sometimes associated with adverse effects on the host including hypersensitivity, immunesuppression and allergic reactions. Therefore, there is a need to develop alternative antimicrobial drugs for the treatment of infectious diseases from medicinal plants $[1,2]$.

Antimicrobials of plant origin have enormous therapeutic potential. They are effective in the treatment of infectious diseases while simultaneously mitigating many of the side effects that are often associated with synthetic antimicrobials [3]. The beneficial medicinal effects of plant materials typically result from the combinations of secondary products present in the plant. Secondary products extracted from different parts of the plants can be used to cure diarrhea, dysentery, cough, cold, cholera, fever, bronchitis, etc.

The drug-resistant bacteria and fungal pathogens have further complicated the treatment of infectious diseases. In recent years, drug resistance to human pathogenic bacteria has been commonly reported from all over the world.
However, the situation is alarming in developing as well as developed countries due to indiscriminate use of antibiotics [4]. In the present scenario of emergence of multiple drug resistance to human pathogenic organisms, this has necessitated a search for new antimicrobial substances from natural sources including plants. Plant and plant products play a wide range of antimicrobial properties. Keeping in view, the present study to investigate the antimicrobial properties of Caralluma indica.

\section{Material and Methods}

Plant materials: The whole plant of Caralluma indica Stems were collected from Kathattipatti (Palaiyapatti North) Thanjavur, Tamil Nadu, India. The plant was identified and authenticated by Dr. S. John Britto, The Director, the Rapinat Herbarium and center for molecular systematics, St. Joseph's college Trichy-Tamil Nadu. India. A Voucher specimen has been deposited at the Rabinat Herbarium, St. Josephs College, Thiruchirappalli, Tamil nadu, India.

Preparation of extracts: The collected Caralluma indica stems were washed several times with distilled water to remove the traces of impurities from the plant. The stem was cut into small pieces and ground in to fine powder using mechanical grinder. The powder was extracted with ethanol for 24 hours. A semi solid extract was obtained after 
complete elimination of alcohol under reduced pressure. The Caralluma indica stem extract was stored in refrigerator until used.

Determination of antimicrobial activity: Antibiogram was done by disc diffusion method [5,6] using plant extracts. Petri plates were prepared by pouring $30 \mathrm{ml}$ of NA /PDA medium for bacteria/fungi. The test organism was inoculated on solidified agar plate with the help of micropipette and spread and allowed to dry for 10 mints. The surfaces of media were inoculated with bacteria/fungi from a broth culture. A sterile cotton swab was dipped into a standardized bacterial/ fungi test suspension and used to evenly inoculate the entire surface of the Nutrient agar/PDA plate. Briefly, inoculums containing bacteria specie were spread on Nutrient agar plates and fungus strains were spread on potato dextrose agar. Using sterile forceps, the sterile filter papers (6 mm diameter) containing the ethanol extracts $(50 \mu \mathrm{l})$ were laid down on the surface of inoculated agar plate. The plates were incubated at $37^{\circ} \mathrm{C}$ for $24 \mathrm{~h}$ for the bacteria and at room temperature $(30 \pm 1)$ for $24-48 \mathrm{hr}$. for yeasts strains. Each sample was tested in triplicate.

\section{RESULTS AND DISCUSSION}

The different concentrations of Caralluma indica stem were screened against Escherichia coli, Staphylococcus aureus, Bacillus subtilis and Pseudomonas aeruginos species of bacteria and Candida albicans, Aspergillus flavus and Aspergillus niger species of fungal were evaluated using the standard agar disc diffusion method. The solidified Nutrient agar plates were swapped with the test organism and the samples were impregnated. After the incubation the zone was measured. The antimicrobial activity of Caralluma indica stem extract was detected by the indication of zone around the disc. The in vitro antimicrobial activities of the Caralluma indica stem extract against these microbes were qualitatively assessed by the presence of inhibition zones represented in the photographic Figure 1 and 2. The inhibitory activities in culture media of the Microbes reported in Table 1 and 2 are comparable with standard antimicrobiotic viz. chloramphenicol (bacteria) and Fluconazole (fungal).

After incubation, the inhibitory effect of Caralluma indica stem extract are significant as compared to standard. Zone of inhibition ( $\mathrm{ZoI})$ is used as a measure for comparing microbial activity of these Caralluma indica stem extract. It shows about $3.92 \mathrm{~mm}(50 \mu \mathrm{l}), 6.11 \mathrm{~mm}(100 \mu \mathrm{l}), 8.25 \mathrm{~mm}$ $(150 \mu \mathrm{l})$ and $10.98 \mathrm{~mm}$ (Std.) zone against the test organisms of Escherichia coli. $4.08 \mathrm{~mm}(50 \mu \mathrm{l}), 6.23 \mathrm{~mm}(100 \mu \mathrm{l})$, $8.47 \mathrm{~mm}(150 \mu \mathrm{l})$ and $11.65 \mathrm{~mm}$ (Std.) zone against the test

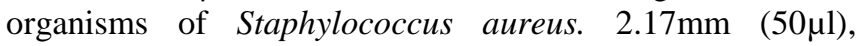
$4.86 \mathrm{~mm}(100 \mu \mathrm{l}), 6.13 \mathrm{~mm}(150 \mu \mathrm{l})$ and $9.46 \mathrm{~mm}$ (Std.) zone against the test organisms of Bacillus subtilis and $4.85 \mathrm{~mm}$ $(50 \mu \mathrm{l}), 7.32 \mathrm{~mm}(100 \mu \mathrm{l}), 9.69 \mathrm{~mm}(150 \mu \mathrm{l})$ and $12.13 \mathrm{~mm}$ (Std.) zone against the test organisms of Pseudomonas aeruginos. Antifungal activity shows about $1.95 \mathrm{~mm}(50 \mu \mathrm{l})$, $4.20 \mathrm{~mm}(100 \mu \mathrm{l}), 6.10 \mathrm{~mm}(150 \mu \mathrm{l})$ and $10.42 \mathrm{~mm}$ (Std.) zone against the test organisms of Candida albicans. $0.90 \mathrm{~mm}$ $(50 \mu \mathrm{l}), 2.81 \mathrm{~mm}(100 \mu \mathrm{l}), 5.72 \mathrm{~mm}(150 \mu \mathrm{l})$ and $8.10 \mathrm{~mm}(\mathrm{Std}$. zone against the test organisms of Aspergillus flavus and $0.35 \mathrm{~mm}(50 \mu \mathrm{l}), 1.10 \mathrm{~mm}(100 \mu \mathrm{l}), 3.66 \mathrm{~mm}(150 \mu \mathrm{l})$ and $7.90 \mathrm{~mm}$ (Std.) zone against the test organisms of Aspergillus niger. The highest dose of ethanol extract of Caralluma indica stem possess greater activity against bacterial and fungal.

Table 1 Antibacterial activity of Caralluma indica stem extracts

\begin{tabular}{|l|c|c|c|c|c|}
\hline \multicolumn{1}{|c|}{ Microorganisms } & $\mathbf{5 0} \boldsymbol{\mu \mathbf { l }}$ & $\mathbf{1 0 0} \boldsymbol{\mu l}$ & $\mathbf{1 5 0} \boldsymbol{\mu l}$ & $\begin{array}{c}\text { Standard } \\
(\mathbf{3 0} \boldsymbol{\mu l})\end{array}$ & Control \\
\hline $\begin{array}{l}\text { Escherichia coli } \\
(\mathbf{m m})\end{array}$ & $3.92 \pm 0.27$ & $6.11 \pm 0.43$ & $8.25 \pm 0.58$ & $10.98 \pm 0.77$ & $0.02 \pm 0.001$ \\
\hline $\begin{array}{l}\text { Staphylococcus } \\
\text { aureus }(\mathbf{m m})\end{array}$ & $4.08 \pm 0.29$ & $6.23 \pm 0.44$ & $8.47 \pm 0.59$ & $11.65 \pm 0.82$ & $0.02 \pm 0.001$ \\
\hline $\begin{array}{l}\text { Bacillus subtilis } \\
(\mathbf{m m})\end{array}$ & $4.85 \pm 0.34$ & $7.32 \pm 0.51$ & $9.69 \pm 0.68$ & $12.13 \pm 0.85$ & $0.03 \pm 0.001$ \\
\hline $\begin{array}{l}\text { Pseudomonas } \\
\text { aeruginos }(\mathbf{m m})\end{array}$ & $2.17 \pm 0.15$ & $4.86 \pm 0.34$ & $6.13 \pm 0.43$ & $9.46 \pm 0.66$ & $0.02 \pm 0.001$ \\
\hline
\end{tabular}

Values are expressed as Mean \pm SD

Bacterial standard : Chloramphenicol

Control : Ethanol 


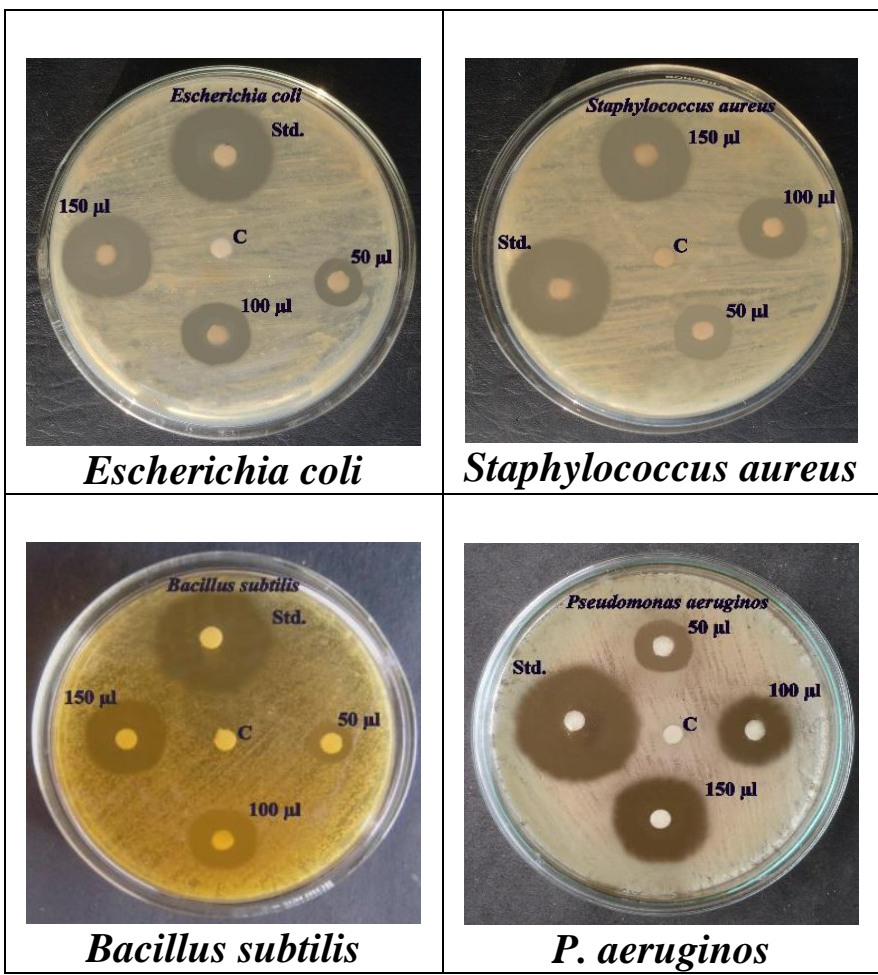

Figure 1 Antibacterial activity of Caralluma indica stem extracts

Table 2 Antifungal activity of Caralluma indica stem extracts

\begin{tabular}{|l|c|c|c|c|c|}
\hline \multicolumn{1}{|c|}{ Microorganisms } & $\mathbf{5 0} \boldsymbol{\mu l}$ & $\mathbf{1 0 0} \boldsymbol{\mu l}$ & $\mathbf{1 5 0} \boldsymbol{\mu l}$ & $\begin{array}{c}\text { Standard } \\
(\mathbf{3 0} \boldsymbol{\mu l})\end{array}$ & Control \\
\hline Candida albicans $(\mathbf{m m})$ & $1.95 \pm 0.14$ & $4.20 \pm 0.29$ & $6.10 \pm 0.43$ & $10.42 \pm 0.73$ & $0.03 \pm 0.001$ \\
\hline Aspergillus flavus $(\mathbf{m m})$ & $0.90 \pm 0.06$ & $2.81 \pm 0.20$ & $5.72 \pm 0.40$ & $8.10 \pm 0.57$ & $0.04 \pm 0.001$ \\
\hline Aspergillus niger $(\mathbf{m m})$ & $0.35 \pm 0.02$ & $1.10 \pm 0.08$ & $3.66 \pm 0.26$ & $7.90 \pm 0.55$ & $0.03 \pm 0.001$ \\
\hline
\end{tabular}

Values are expressed as Mean \pm SD

Fungal standard : $\quad$ Fluconazole

Control : Ethanol

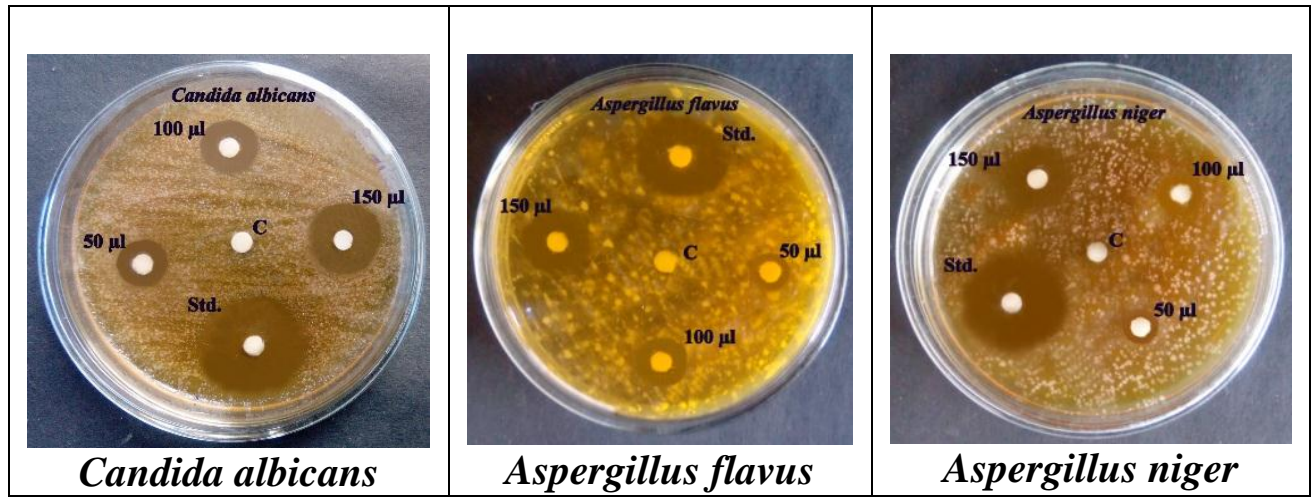

Figure 2 Antifungal activity of Caralluma indica stem extracts 
Dagmar Janovyska et al. [7] tested the antimicrobial activity of crude ethanolic extracts of 10 medicinal plants used in traditional medicine against five species of microorganisms: Bacillus cereus, Escherichia coli, Staphylococcus aureus, Pseudomonas aeruginosa and Candida albicans of the 10 plants tested, 5 showed antimicrobial activity against one or more species of microorganisms. The most active antimicrobial plants were Chelidonium majus, Sanguisorba officinalis and Tussilago farfara.

The petroleum ether, benzene ethyl acetate and acetone extract of Galinisoga ciliate bark displays higher activity against Gram positive bacteria (Staphylococcus aureus and Bacillus subtilis) rather than Gram the negative bacteria (Pseudomonas aeruginosa and Escherichia coli). The toxicity against microorganisms may be done to the high amount of phenolic compounds present [8].

Screened the pharmacological activity of the ethanol and acetone extract of Phyllanthus amarus, Acalypha and indica Datura metel for its antimicrobial activity against selected pathogen. The antimicrobial activity was determined by using Disc diffusion method. Ethanol and acetone extracts with different concentrations $(100 \mathrm{mg} / \mathrm{ml}$, $200 \mathrm{mg} / \mathrm{ml}$ and $300 \mathrm{mg} / \mathrm{ml}$ ) were mixed with $1 \mathrm{ml}$ of Dimethyl sulfoxide (DMSO). The inhibitory effect of ethanol extract was relatively high when compared to acetone extract. The study of antimicrobial activity of herbal plant extract of Datura metel, Acalypha indica and Phyllanthus amarus showed that the ethanol extract shows promising antimicrobial activity against bacterial and fungal human pathogens when compared to acetone extract [9].

\section{CONCLUSION}

From the experiment it was concluded that the various concentrations of Caralluma indica stem possess antimicrobial property against human pathogens. The Caralluma indica stem is having potential antibacterial and antifungal property. Since Caralluma indica stem are abundant in nature, cost effective and easy to be processed, they are a promising solution for a variety of health problems in the near future. The medicinal properties of these Caralluma indica stem can be exploited to formulate drugs for several diseases caused by antibiotic resistant pathogenic microorganisms. In this way, suggested that Caralluma indica stem may be considered as an easily available bioresource for antimicrobial agent.

\section{REFERENCE}

[1] P. Agrawal, V. Rai, and R. B. Singh, Randomized, placebo controlled, single-blind trial of holy basil leaves in patients with noninsulin-dependent Diabetes mellitus. International Journal of
Clinical Pharmacology and Therapeutics, Volume 34, pp 406-409, 1996.

[2] J. Parekh, D. Jadeja, and S. Chanda. Efficacy of Aqueous and Methanol Extracts of Some Medicinal Plants for Potential Antibacterial Activity. Turkey Journal of Biology, Volume 29, pp 203-210, 2005.

[3] S. Ramasamy, and Charles Manoharan, Antibacterial effect of volatile components of selected medicinal plants against human pathogens. Asian Journal of Microbiology, Biotechnology and Environmental Science, Volume 6, pp 209-210, 2004.

[4] P. Saranraj, and D. Stella, Antibiogram of nosocomial infection and its antimicrobial drug resistance. International Journal of Pharmacological and Biological Archives, Volume 2, Issue 6, pp 1598-1610, 2011.

[5] NCCLS. National Committee for Clinical Laboratory Standards. Performance standards for antimicrobial disc susceptibility tests. PA: NCCLS Publications, pp 25, 1993.

[6] O. Awoyinka, I. O. Balogun, and A. A. Ogunnowo, Phytochemical screening and in vitro bioactivity Of Cnidoscolus aconitifolius (Euphorbiaceae). 1 J Med Plant Res., Volume 3, pp 63-65, 2007.

[7] Dagmar Janovska, Katerina Kubikova and Ladislav Kokoska, Screening for antimicrobial activity of some medicinal plants species of traditional Chinese medicine. Czech Journal of Food Science, Volume 21, pp 107-110, 2003.

[8] M. Poonkothai, S. Hema Iswarya, D. Kavitha, and K. Vallikannu, Antibacterial activity of the leaves of Galinsoga ciliate. Asian Journal of Microbiology, Biotechnology and Environmental Science, Volume 7, pp 747-748, 2005.

[9] D. Sekar, K. Kolanjinathan, P. Saranraj, and K. Gajendiran, Screening of Phyllanthus amarus, Acalypha indica and Datura metel for its antimicrobial activity against selected pathogens. International Journal of Pharmaceutical and Biological Archives, Volume 3, Issue 5, pp 1231-1236, 2012. 